INTERNATIONAL JOURNAL OF RESEARCHES IN BIOSCIENCES, AGRICULTURE AND TECHNOLOGY (c) VISHWASHANTI MULTIPURPOSE SOCIETY (Global Peace Multipurpose Socie ty) R. No. MH-659/13(N) www.vmsindia.org

\title{
PISCIVOROUS BIRDS AROUND EKRUKH WATER RESERVOIR OF NORTH SOLAPUR TAHSIL DIST. SOLAPUR (M.S.)
}

\author{
P. V. Darekar, S. H. Chougule, A. C. Kumbhar \\ Dept. of Zoology and Research Centre, \\ Shankarrao Mohite Mahavidyalaya, Akluj, Solapur \\ pvdarekar@gmail.com
}

\begin{abstract}
:
\section{Introduction:}

Water bodies and we tlands help mankind in many ways, such as agriculture, fis hing, sewage disposal, grazing, storage of ground water, tourism, birding, etc. Besides above said facts, they act as the best platform for local and migratory birds for different purposes like breeding, feeding and stopover site. Large number of migratory and resident birds depends on such water bodies and wetlands for their survival. The current study aims to make a checklist of piscivorous birds.

Piscivorous birds feed on fish fauna. They can cause damage to the fish culture by decreasing the yield. Piscivorous birds have been earlier studied by piscivorous birds of Madras were studied by Ghazi (1962), Kulkarni, et.al. (2006), piscivorous birds of minor irrigation dam, Kalamanuri were studied by Waghmare, et.al., Piscivorous birds of HinganiPangaon reservoir, Barshi (M.S.) was studied by Gavhane and Babare (2013). The present research paper reports the check list of piscivorous birds of Ekrukh water reservoir (Hipparaga Lake) of North Solapur Tahsil of Solapur District. (M.S.).
\end{abstract}

Ekrukh water reservoir is one of the largest man made water reservoir. It provides the nutrient rich flora and fauna which attracts the birds. It contains the diverse assemblage of algae, aquatic weeds, phytoplankton, zooplankton which facilitate the growth of fishes like Labeo rohita, Catla catla and other aquatic animals. Ekrukh water re servoir closely located to Solapur city in North Solapur Tahsil. Its total storage capacity is $3330 \mathrm{M}$. Cu. Ft. The water from Ekrukh water tank is currently used for irrigation and drinking. Because of less human disturbance, least pollution and abundant food many birds are attracted towards this reservoir. The lake and its surrounding area acts as the best winter house for many local and migratory birds.

The current study was conducted from March 2014 to February 2015. Total 18 piscivorous birds we re observe d in the study period. Total 18 piscivorous birds were observed in the study period. Out of 18 species 10 birds were re sident, 4 were local migrants, 2 were migrants and 2 was winte $r$ migrant.

Keywords: Ekrukh water rese rvoir, fishes, piscivorous birds, win te $r$ house

\section{Materials and Methods:}

The Ekrukh water reservoir is located at Tale Hipparaga village close to Solapur city. Ekrukh water reservoir is one of the man made water reservoirs constructed very close to Solapur city in Maharashtra and it has a total capacity of $3,330 \mathrm{M}$. Cu. Ft. This reservoir commands a gross area of 17,152 acres. Ekrukh water reservoir is a historical man made water body. The water from Ekrukh water reservoir is utilized for the purpose of irrigation, drinking and farming. The lake and its surrounding area acts as the best winter house for many local and migratory birds. The water body contains a diverse assemblage of resident and migratory birds. Till now, different researchers have studied fau na of piscivorous birds.

The regular survey camps were arranged at morning and evening time of every month, scheduled from March 2014 to February 2015 to find out relative abundance of the birds at study site. For this survey, Olympus binocular was used for bird watching. Photography was done with the help of SLR camera (Canon 1100D) and zoom lenses $(55-210 \mathrm{~mm}$ and 70 300). The obse rved birds were identified with the help of field guides, local bird watchers and pictorial literature. The record of observed birds is maintained by basic bird count and point count me thod.

\section{Result and Discussion:}

Total 18 piscivorous birds were observed in the study period. Out of 18 species 10 birds were resident, 4 were local migrants, 2 were migrants and 2 was winter migrant. As the study period includes monsoon, winter and summer season, the variability in the climate is observed which resulted in the different bird count at the study site. The recorded birds are categorized into resident, local and migratory birds. The availability of variety of food and the nesting behavior of many birds was also studied.

\section{Key to abbreviations:}

First suffix: (Status)

$\mathrm{R}:$ Resident

M: Migrant 
Table 1: Checklist of piscivo rous fauna of Ekrukh water rese rvoir

\begin{tabular}{|c|c|c|c|}
\hline Family & Common Name & Scientific Name & Status \\
\hline Anhingidae & Oriental darter & Anhinga Melamogaster & LM \\
\hline \multirow{2}{*}{ Phalacrocoracidae } & Great cormorant & Phalacrocorax carbo & $R$ \\
\hline & Little cormorant & Phalacrocorax niger & $\mathrm{R}$ \\
\hline \multirow{6}{*}{ Ardeidae } & Indian pond heron & Ardeolagrayü & $\mathrm{R}$ \\
\hline & Grey heron & Ardea cinerea & LM \\
\hline & Little egret & Egretta garzetta & LM \\
\hline & Large egret & Egretta alba & LM \\
\hline & Me dium egret & Egretta intermedia & M \\
\hline & Purple heron & Ardea purpurea & M \\
\hline \multirow{2}{*}{ Ciconidae } & Open bill stork & Anastomus oscitans & $\mathrm{R}$ \\
\hline & Painted stork & Mycteria leucocephala & $\mathrm{R}$ \\
\hline \multirow{2}{*}{ Anatidae } & Ruddy shell duck & Tadorna ferruginea & WM \\
\hline & Bar headed goose & Anser indicus & WM \\
\hline Accipitridae & Brahminy kite & Halias tur indis & $\mathrm{R}$ \\
\hline Laridae & River tern & Sterna aurantia & $\mathrm{R}$ \\
\hline \multirow{3}{*}{ Alcedinidae } & Small kingfisher & Alce do atthis & $\mathrm{R}$ \\
\hline & Pied kingfisher & Ceryl erudis & $\mathrm{R}$ \\
\hline & $\begin{array}{l}\text { White breasted } \\
\text { kingfisher }\end{array}$ & Halcyon smymensis & $\mathrm{R}$ \\
\hline
\end{tabular}

Family wise no. of bird species

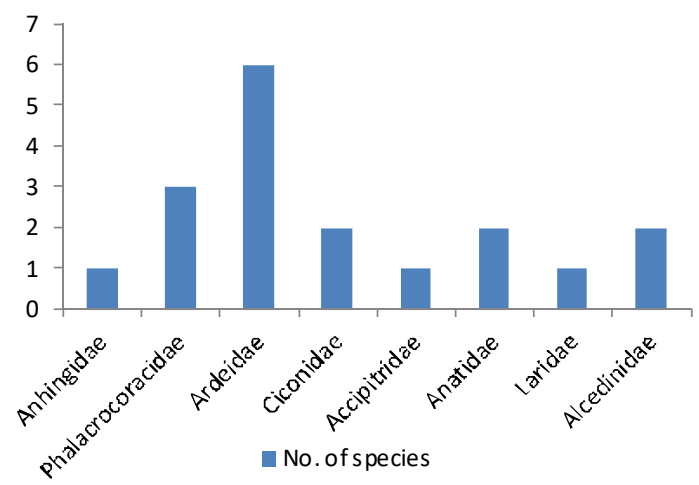

Chart: 1: Chart showing the family wise number of piscivo rous birds

\section{Conclusion:}

Total 18 piscivorous birds were observed in the study period. Out of 18 species 10 birds were resident, 4 were local migrants, 2 were migrants and 2 was winter migrant. During the study period, water level on the reservoir was varied seaso nally. No poaching of

Chart: 2: Chart showing the status of obse rved
Re sidential status of birds

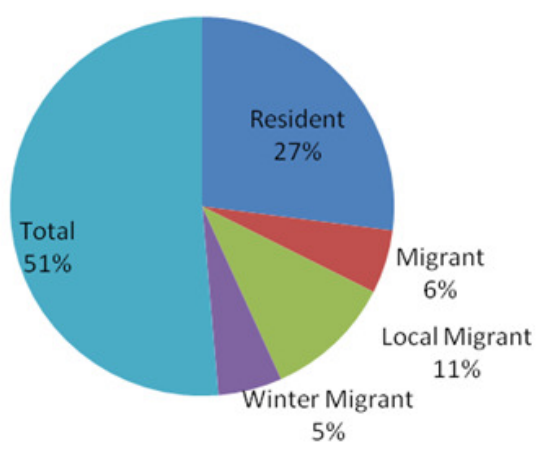

piscivorous birds

the bird was observed during the study period. The reservoir was with less human interference and least pollution was observed at the study site. All these parameters make the reservoir the excellent place for many species of birds. This natural beauty of the reservoir must be preserved and the area should be kept free from pollution and human disturbances. 


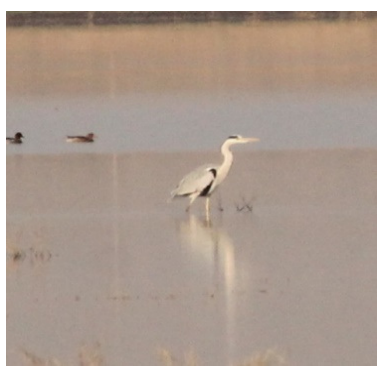

Fig. 1.1 Grey heron

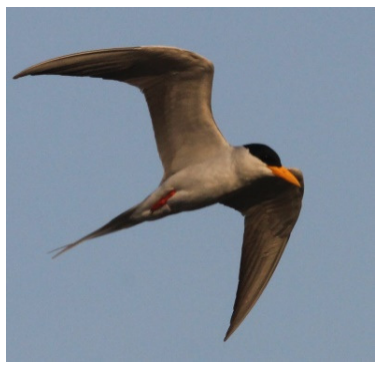

Fig. 1.4 River tern

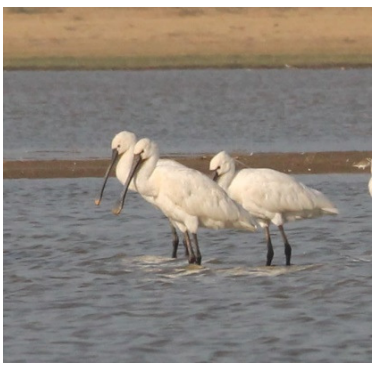

Fig. 1.7 Spoon bills

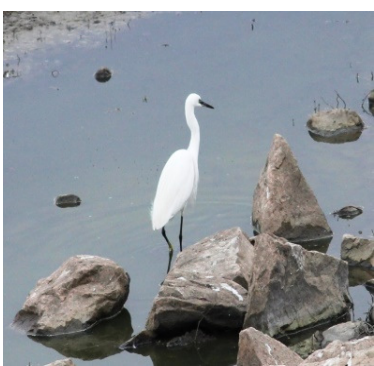

Fig. 1.2 Large egret

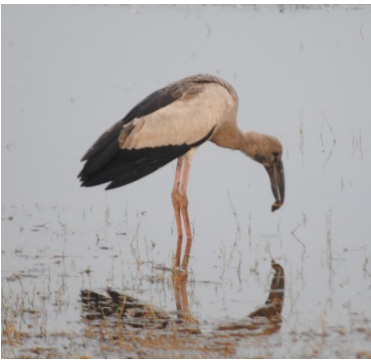

Fig. 1.5 Open bill stork

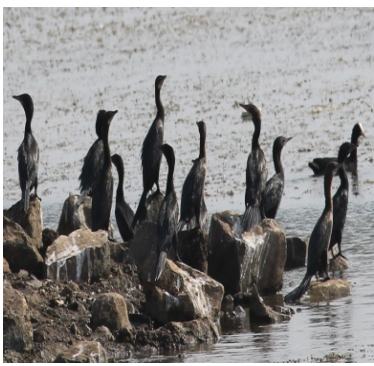

Fig. 1.8 Great cormorants

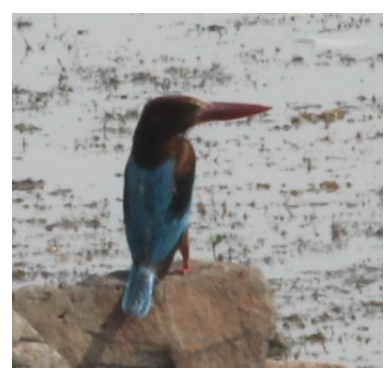

Fig. 1.3 White breasted kingfisher

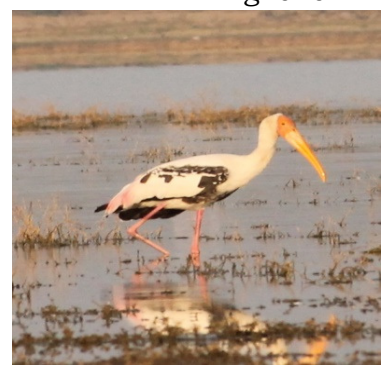

Fig. 1.6 Painted stork

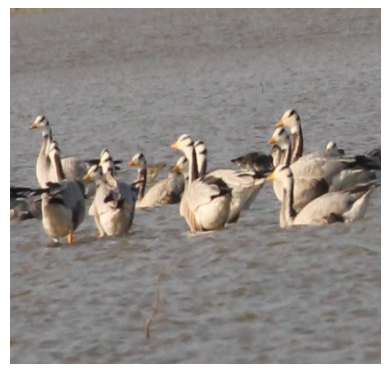

Fig. 1.9 Bar headed goose

Fig : Photographs of the piscivorous birds found at Ekrukh Lake

\section{References:}

1. Ghazi, H.K., 1962, Piscivorous birds of madras J. of Fis heries, 1(1):106-107.

2. Kulkarni, A.N. and Kanwate, V.S. 2006, Piscivorous birds of Dangarheda irrigation tank, DistHingoli (M.S.) J. Aqua. Bio. 29 (1) : 86-87.

3. Waghmare, et.al, Piscivorous birds of minor irrigation dam, Kalamanuri, Dist Hingoli (M.S.) J. Aqua. Bio.
4. U.V. Gavhane and M.G. Babare, Piscivorus Birds Of Hingani-Pangaon Reservoir, Barshi (M.S.) India, Research Front, (Print) 2320 6446, (Online), Vol. 1, No. 1, March, 2013: 93-96

5. Salim Ali. 2012. Indian Birds, Bombay Natural History Society, Oxford University press 